\title{
Studies on storage quality evaluation of drink prepared from Rhododendron (Rhododendron arboreum $\mathrm{Sm}$.) flowers extract
}

\author{
N.S. Thakur, Aarti, Abhimanyu Thakur», Surekha Attri, Hamid and Sunakshi Gautam \\ Department of Food Science and Technology, Dr Yashwant Singh Parmar University of Horticulture and Forestry, Nauni, Solan-173230, \\ Himachal Pradesh, India
}

\begin{tabular}{|c|c|}
\hline Article Info & Abstract \\
\hline Article history & \multirow{6}{*}{$\begin{array}{l}\text { Rhododendron (Rhododendron arboreum Sm.) is one of the wild flower of Himachal Pradesh (India) } \\
\text { which can be of great economic importance because of its high antioxidants, colour pigments and other } \\
\text { quality parameters besides its medicinal properties. Drink or RTS beverage is quite popular product because } \\
\text { of longer shelf-life and less loss of nutrients during processing. In present investigation, effect of packaging } \\
\text { and storage conditions on the various quality parameters of rhododendron drink was studied. The physico- } \\
\text { chemical and sensory characteristics of rhododendron drink packed in pre-sterilized glass and PET } \\
\text { (Polyethylene terephthalate) bottles stored in ambient }\left(20-25^{\circ} \mathrm{C}\right) \text { and refrigerated temperature }\left(4-7^{\circ} \mathrm{C}\right)\end{array}$} \\
\hline Received 10 May 2021 & \\
\hline Revised 27 June 2021 & \\
\hline Accepted 28 June 2021 & \\
\hline Published online 30 June 2021 & \\
\hline Keywords & \\
\hline Antioxidant & conditions were estimated at 0,3 and 6 months of storage. Drink could be safely stored for a period of six \\
\hline Drink & months under both the storage conditions without much change in the various physicochemical and \\
\hline Packaging & sensory characteristics. The various physicochemical characteristics like total soluble solids (12.00 to \\
\hline Rhododendron & $\left.12.47^{\circ} \mathrm{B}\right)$, reducing sugars $(7.05$ to $8.62 \%)$, titratable acidity $(0.30$ to $0.26 \%)$, ascorbic acid (1.43 to 0.28 \\
\hline RTS & $\begin{array}{l}\mathrm{mg} / 100 \mathrm{ml}) \text {, anthocyanins }(9.68 \text { to } 6.33 \mathrm{mg} / 100 \mathrm{ml}) \text {, total phenols }(14.24 \text { to } 12.63 \mathrm{mg} \mathrm{GAE} / 100 \mathrm{ml}) \text { and } \\
\text { antioxidant activity }(9.66 \text { to } 7.44 \%) \text { increased/decreased during the storage period. However, these } \\
\text { changes were slower in refrigerated storage conditions as compared to that under ambient conditions. The } \\
\text { drink stored in PET and glass bottles was found suitable for consumption, with comparatively less changes } \\
\text { occurring in glass bottles stored under refrigerated conditions. }\end{array}$ \\
\hline
\end{tabular}

\section{Introduction}

Rhododendron (Rhododendron arboreum Sm.) commonly known as "Burans" is an evergreen shrub or small tree with highly valued wild edible flowers. The term rhododendron has been derived from two Greek words "rhodo" and "dendron" which means rose and tree, respectively. So, the rhododendron can be regarded as rose tree (Srivastava, 2012). It belongs to family Ericaceae, comprising of 8 genera and 850 species which is mainly found growing between 1500 and 2400 meters above mean sea level (Stevens et al., 2004; Sharma et al., 2009; Negi et al., 2013). The genus is mostly concentrated in the temperate regions of northern hemisphere (especially in Eastern Himalayas and Western China) and further extended towards southern China as well as to north-eastern China and Japan (Bhattacharyya and Sanjappa, 2008). In India, 80 species of rhododendron are found in various states like Arunachal Pradesh, Himachal Pradesh, Jammu and Kashmir, Manipur, Nagaland, Sikkim and Uttrakhand (Katoch, 2014). In Himachal Pradesh, three species, namely; Rhododendron arboreum $\mathrm{Sm}$., Rhododendron campanulatum D. and Rhododendron anthopogen $\mathrm{D}$. are distributed in the forests of Bilaspur, Sirmour, Chamba, Kangra, Kullu, Shimla, Kinnaur and Solan districts (Pradhan and Lachungpa, 1990; Chauhan, 1999). The flowers of rhododendron are deep red to scarlet red

\section{Corresponding author: Dr. Abhimanyu Thakur}

Assistant Professor, Department of Food Science and Technology, Dr. Yashwant Singh Parmar University of Horticulture and Forestry, Nauni, Solan-173230, Himachal Pradesh, India

E-mail: abhimanyuthakurprashar@gmail.com Tel.: +91-9882239719

Copyright () 2021 Ukaaz Publications. All rights reserved.

Email: ukaaz@yahoo.com; Website: www.ukaazpublications.com with sweetish sour taste and have been found to be rich source of carbohydrates, amino acids, sugars, pectin, anthocyanins and vitamin C (Solanki et al., 2013; Purohit, 2014; Kashyap et al., 2017). The health benefits of rhododendron flowers includes prevention and treatment of diseases associated with heart, dysentery, diarrhea, detoxification, inflammation, fever, constipation, bronchitis and asthma. These flowers are traditionally used in the preparation of various value added products like pickle, juice, jam, syrup, honey, squash, etc. (Nisar et al., 2013; Kumar et al., 2019). Shelf life of various value added products is the maximum time during which the food retains an acceptable quality and can be used safely under specified environmental conditions of temperature, moisture and exposure to light. It generally depends upon various factors like packaging and storage conditions which play an important role in retaining the nutritional, sensory and microbiological quality along with enhanced shelf-life of any processed product during handing, transportation and storage (Sharma and Thakur, 2019). Thus, the present study was undertaken to evaluate the effect of storage and packaging material on different quality characteristics of rhododendron drink prepared by prestandardized recipe.

\section{Materials and Methods}

\subsection{Raw material and preparation of rhododendron drink}

The flowers of Rhododendron arboreum Sm. procured from Rajgarh area of Sirmour district of Himachal Pradesh. The flower identification and authentication was carried out by Department of Forest Products, Dr. YSPUHF, Nauni, Solan, India vide-UHF 
herbarium number-13915, YSPUHF, Solan, India. For preparation of rhododendron drink, recipe standardized by Thakur et al. (2021 a) consisting of 14 per cent extract, $12^{\circ} \mathrm{B}$ TSS and 0.30 per cent acidity was used.

\subsection{Packaging and storage of beverages}

After the preparation, i.e., drink it was further packed in pre-sterilized glass and PET bottles, each of $200 \mathrm{ml}$ capacity. All the packed products were properly labelled and stored in ambient $\left(20-25^{\circ} \mathrm{C}\right)$ and refrigerated temperature $\left(4-7^{\circ} \mathrm{C}\right)$ conditions for six months. The physicochemical and organoleptic characteristics of all the products were estimated at zero, three and six months of storage.

\subsection{Physicochemical analysis and sensory evaluation}

The colour of rhododendron drink in terms of different units (Red and Yellow) was observed with Lovibond Tintometer Model-E. The apparent viscosity of the flower extract and various beverages was determined by using Ostwald viscometer and was expressed in terms of time (flow rate in minutes) taken for samples to pass through the tube. TSS, sugars, titratable acidity, ascorbic acid and anthocyanins content of RTS drink were determined according to the standard procedures (Ranganna, 2009). The $\mathrm{pH}$ of drink was determined by using a digital $\mathrm{pH}$ meter (CRISON Instrument, Ltd. Spain). Total phenols content was determined by Folin-Ciocalteu procedure given by Singleton and Rossi (1965) whereas, antioxidant activity (Free radical scavenging activity) was measured as per the method of Brand-Williams et al. (1995). Nine point hedonic rating test was followed for conducting the sensory evaluation of rhododendron drink (Amerine et al., 1965). The panel of ten judges comprising of faculty members and students of department of FST, Dr. Y.S. Parmar University of Horticulture and Forestry, Nauni, Solan (HP) were selected to evaluate the products for sensory parameters like colour, body, taste, aroma and overall acceptability. This random selection was made so as to accommodate different sections and age groups to evaluate the various sensory parameters (Thakur et al., 2018a).

\subsection{Statistical analysis}

During storage, data on physicochemical characteristics of rhododendron drink was analysed by completely randomized design (CRD) during storage, whereas, data pertaining to the sensory evaluation were analyzed by using randomized block design (RBD). The data for various physicochemical and sensory characteristics was replicated five times.

\section{Results}

\subsection{Storage of rhododendron drink}

Data pertaining to effect of storage on various physicochemical and sensory characteristics of rhododendron drink have been presented in Tables 1 to 17 and Figures 1 to 5 .

Table 1: Effect of packaging on red TCU of rhododendron drink during storage

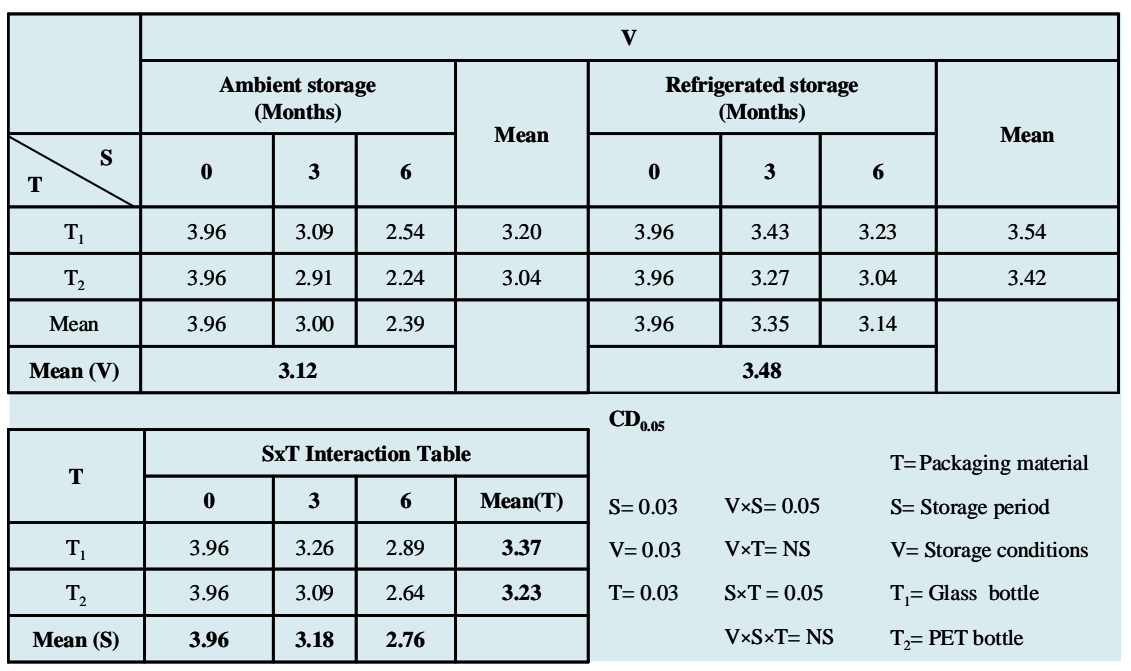

\subsubsection{Physicochemical characteristics}

\subsubsection{Colour and apparent viscosity}

Data of visual colour of drink measured by tintometer colourimeter in the form of red TCU have been given in the Table 1 and Figure 1a which reveal a general decrease in the red TCU of rhododendron drink during storage. The overall effect of storage period and storage conditions on the red TCU of drink indicate that they decreased from 3.96 to 2.76 , retained more (3.48) in refrigerated storage conditions as compared to ambient storage conditions (3.12). The product packed in glass bottle retained higher (3.37) red TCU and lower (3.23) in PET bottle while comparing overall effect of packaging materials on red TCU of this product. Data in the Table 2 and Figure $1 \mathrm{~b}$ reveal that yellow TCU of drink decreased during storage and this decrease was from 0.55 to 0.25 , retained higher (0.39) and lower (0.34) in refrigerated and ambient storage conditions, respectively. The overall effect of packaging material shows that more (0.39) yellow TCU were retained in glass bottle as compared to PET bottle (0.35). The data in Table 3 and Figure 1c indicates a general increasing trend in apparent viscosity (flow rate in minutes) of drink during entire storage period. However, the overall effect of storage period shows that there was a significant increase in apparent viscosity from 5.11 to 5.40 . The overall effect of storage conditions and packaging materials on apparent viscosity of drink was found to be non significant. 
Table 2: Effect of packaging on yellow TCU of rhododendron drink during storage

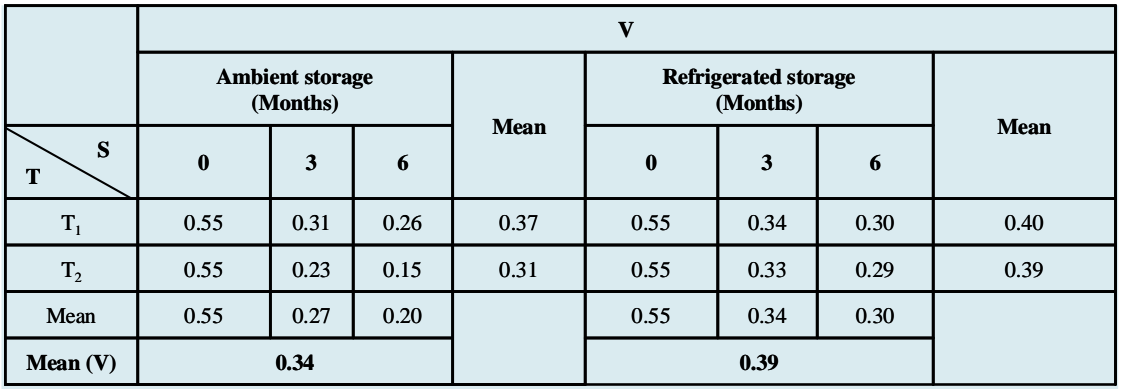

\begin{tabular}{|c|c|c|c|c|}
\hline \multirow{2}{*}{$T$} & \multicolumn{4}{|c|}{ SxT Interaction Table } \\
\cline { 2 - 5 } & $\mathbf{0}$ & $\mathbf{3}$ & $\mathbf{6}$ & Mean(T) \\
\hline $\mathrm{T}_{1}$ & 0.55 & 0.33 & 0.28 & $\mathbf{0 . 3 9}$ \\
\hline $\mathrm{T}_{2}$ & 0.55 & 0.28 & 0.22 & $\mathbf{0 . 3 5}$ \\
\hline Mean (S) & $\mathbf{0 . 5 5}$ & $\mathbf{0 . 3 0}$ & $\mathbf{0 . 2 5}$ & \\
\hline
\end{tabular}

$\begin{array}{lll}\mathbf{C D}_{0.05} & & \\ & & \mathrm{~T}=\text { Packaging material } \\ \mathrm{S}=0.02 & \mathrm{~V} \times \mathrm{S}=0.04 & \mathrm{~S}=\text { Storage period } \\ \mathrm{V}=0.02 & \mathrm{~V} \times \mathrm{T}=0.03 & \mathrm{~V}=\text { Storage conditions } \\ \mathrm{T}=0.02 & \mathrm{~S} \times \mathrm{T}=\mathrm{NS} & \mathrm{T}_{1}=\text { Glass bottle } \\ & \mathrm{V} \times \mathrm{S} \times \mathrm{T}=\mathrm{NS} & \mathrm{T}_{2}=\text { PET bottle }\end{array}$

Table 3: Effect of packaging on apparent viscosity (min.) of rhododendron drink during storage

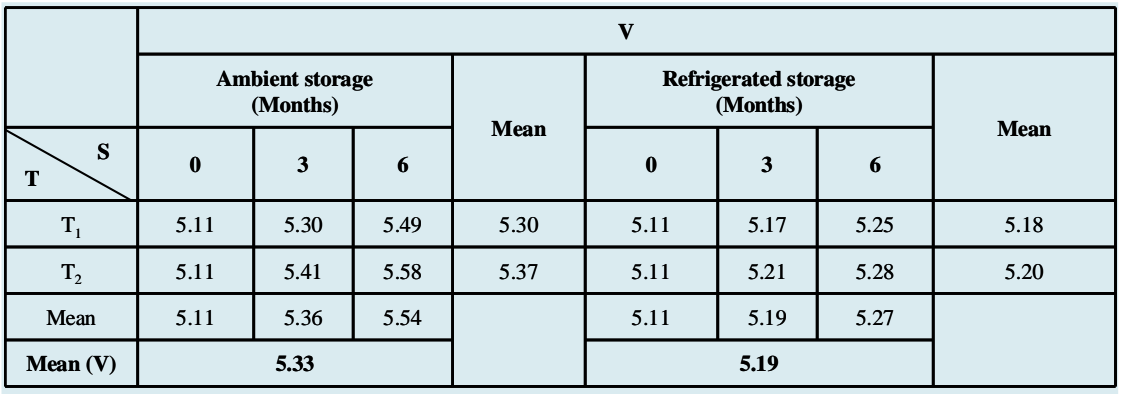

\begin{tabular}{|c|c|c|c|c|}
\hline \multirow{2}{*}{$T$} & \multicolumn{4}{|c|}{ SxT Interaction Table } \\
\cline { 2 - 5 } & $\mathbf{0}$ & $\mathbf{3}$ & $\mathbf{6}$ & Mean(T) \\
\hline $\mathrm{T}_{1}$ & 5.11 & 5.24 & 5.37 & $\mathbf{5 . 2 4}$ \\
\hline $\mathrm{T}_{2}$ & 5.1 & 5.31 & 5.43 & $\mathbf{5 . 2 8}$ \\
\hline Mean (S) & $\mathbf{5 . 1 1}$ & $\mathbf{5 . 2 7}$ & $\mathbf{5 . 4 0}$ & \\
\hline
\end{tabular}

$\begin{array}{lll}\mathrm{CD}_{0.05} & & \\ & & \mathrm{~T}=\text { Packaging material } \\ \mathrm{S}=0.19 & \mathrm{~V} \times \mathrm{S}=\mathrm{NS} & \mathrm{S}=\text { Storage period } \\ \mathrm{V}=\mathrm{NS} & \mathrm{V} \times \mathrm{T}=\mathrm{NS} & \mathrm{V}=\text { Storage conditions } \\ \mathrm{T}=\mathrm{NS} & \mathrm{S} \times \mathrm{T}=\mathrm{NS} & \mathrm{T}_{1}=\text { Glass bottle } \\ & \mathrm{V} \times \mathrm{S} \times \mathrm{T}=\mathrm{NS} & \mathrm{T}_{2}=\text { PET bottle }\end{array}$

Table 4: Effect of packaging on TSS $\left({ }^{\circ} B\right)$ of rhododendron drink during storage

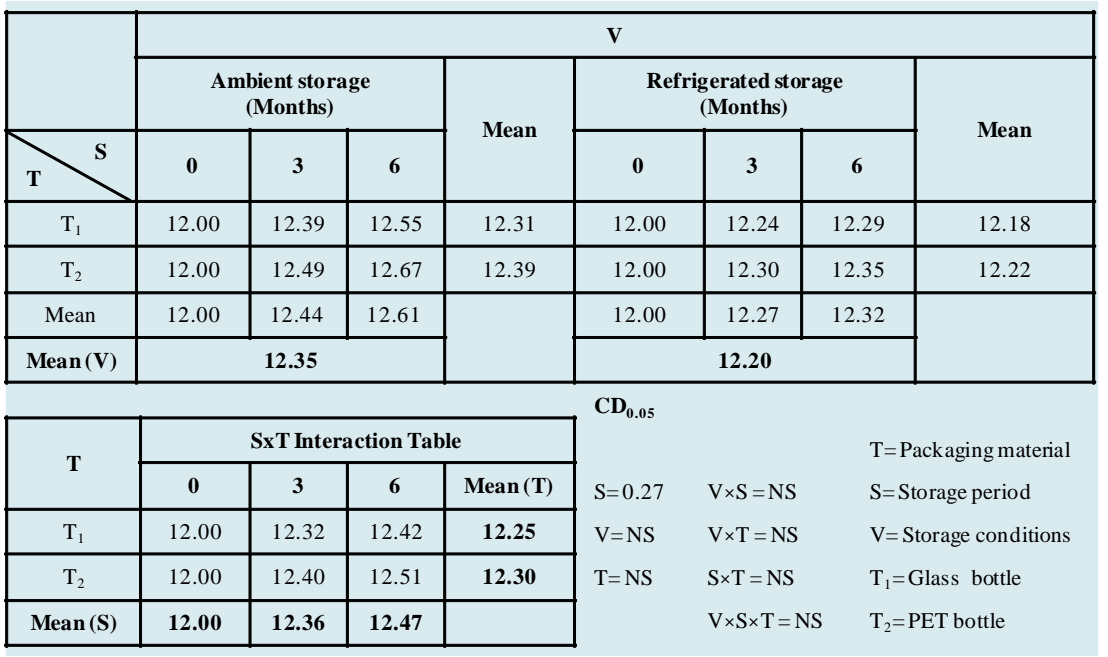


Table 5: Effect of packaging on reducing sugars (\%) of rhododendron drink during storage

\begin{tabular}{|c|c|c|c|c|c|c|c|c|}
\hline \multirow[b]{3}{*}{$\mathrm{T}$} & \multicolumn{8}{|c|}{$\mathbf{v}$} \\
\hline & \multicolumn{3}{|c|}{$\begin{array}{c}\text { Ambient storage } \\
\text { (Months) }\end{array}$} & \multirow{2}{*}{ Mean } & \multicolumn{3}{|c|}{$\begin{array}{l}\text { Refrigerated storage } \\
\text { (Months) }\end{array}$} & \multirow{2}{*}{ Mean } \\
\hline & $\mathbf{0}$ & 3 & 6 & & $\mathbf{0}$ & 3 & 6 & \\
\hline $\mathrm{T}_{1}$ & 7.05 & 9.33 & 9.50 & 8.63 & 7.05 & 7.20 & 7.46 & 7.24 \\
\hline $\mathrm{T}_{2}$ & 7.05 & 9.55 & 9.82 & 8.81 & 7.05 & 7.40 & 7.71 & 7.39 \\
\hline Mean & 7.05 & 9.44 & 9.66 & & 7.05 & 7.30 & 7.59 & \\
\hline Mean (V) & \multicolumn{3}{|c|}{8.72} & & \multicolumn{3}{|c|}{7.31} & \\
\hline & & & & & $\mathrm{CD}_{0.05}$ & & & \\
\hline \multirow{2}{*}{$\mathbf{T}$} & \multicolumn{4}{|c|}{ SxT Interaction Table } & \multirow{5}{*}{$\begin{array}{l}S=N S \\
V=N S \\
T=N S\end{array}$} & \multirow[b]{2}{*}{$\mathrm{V} X \mathrm{~S}=\mathrm{NS}$} & \multirow{2}{*}{\multicolumn{2}{|c|}{$\begin{array}{l}\mathrm{T}=\text { Packaging material } \\
\mathrm{S}=\text { Storage period }\end{array}$}} \\
\hline & $\mathbf{0}$ & 3 & 6 & Mean (T) & & & & \\
\hline $\mathrm{T}_{1}$ & 7.05 & 8.27 & 8.48 & 7.93 & & \multirow{2}{*}{$\begin{array}{l}V \times T=N S \\
S \times T=N S\end{array}$} & \multicolumn{2}{|c|}{$\mathrm{V}=$ Storage conditions } \\
\hline $\mathrm{T}_{2}$ & 7.05 & 8.48 & 8.77 & 8.10 & & & & $=$ Glass bottle \\
\hline Mean (S) & 7.05 & 8.37 & 8.62 & & & \multicolumn{2}{|c|}{$\mathrm{V} \times \mathrm{S} \times \mathrm{T}=\mathrm{NS}$} & $\mathrm{T}_{2}=$ PET bottle \\
\hline
\end{tabular}

Table 6: Effect of packaging on total sugars (\%) of rhododendron drink during storage

\begin{tabular}{|c|c|c|c|c|c|c|c|c|}
\hline \multirow[b]{3}{*}{$\mathrm{T}$} & \multicolumn{8}{|c|}{$\mathbf{v}$} \\
\hline & \multicolumn{3}{|c|}{$\begin{array}{c}\text { Ambient storage } \\
\text { (Months) }\end{array}$} & \multirow{2}{*}{ Mean } & \multicolumn{3}{|c|}{$\begin{array}{l}\text { Refrigerated storage } \\
\text { (Months) }\end{array}$} & \multirow{2}{*}{ Mean } \\
\hline & o & 3 & 6 & & o & 3 & 6 & \\
\hline $\mathrm{T}_{1}$ & 9.98 & 10.41 & 10.75 & 10.38 & 9.98 & 10.12 & 10.21 & 10.10 \\
\hline $\mathrm{T}_{2}$ & 9.98 & 10.58 & 10.89 & 10.48 & 9.98 & 10.18 & 10.26 & 10.14 \\
\hline Mean & 9.98 & 10.50 & 10.82 & & 9.98 & 10.15 & 10.24 & \\
\hline Mean (V) & \multicolumn{3}{|c|}{10.43} & & \multicolumn{3}{|c|}{10.12} & \\
\hline
\end{tabular}

\begin{tabular}{|c|c|c|c|c|c|c|c|}
\hline & & & & & \multirow{2}{*}{\multicolumn{2}{|c|}{$\mathbf{C D}_{0.05}$}} & \multirow{3}{*}{$\begin{array}{l}\mathrm{T}=\text { Packaging materia } \\
\mathrm{S}=\text { Storage period }\end{array}$} \\
\hline \multirow{2}{*}{$\mathbf{T}$} & \multicolumn{4}{|c|}{ SxT Interaction Table } & & & \\
\hline & $\mathbf{0}$ & 3 & 6 & $\operatorname{Mean}(\mathbf{T})$ & \multirow{4}{*}{$\begin{array}{l}S=N S \\
V=N S \\
T=N S\end{array}$} & $\mathrm{~V} \times \mathrm{S}=\mathrm{NS}$ & \\
\hline$T_{1}$ & 9.98 & 10.27 & 10.48 & 10.24 & & $\mathrm{~V} \times \mathrm{T}=\mathrm{NS}$ & $\mathrm{V}=$ Storage conditions \\
\hline $\mathrm{T}_{2}$ & 9.98 & 10.38 & 10.58 & 10.31 & & $\mathrm{~S} \times \mathrm{T}=\mathrm{NS}$ & $T_{1}=$ Glass bottle \\
\hline Mean (S) & 9.98 & 10.32 & 10.53 & & & $\mathrm{~V} \times \mathrm{S} \times \mathrm{T}=\mathrm{NS}$ & $\mathrm{T}_{2}=$ PET bottle \\
\hline
\end{tabular}

Table 7: Effect of packaging on titratable acidity (\%) of rhododendron drink during storage

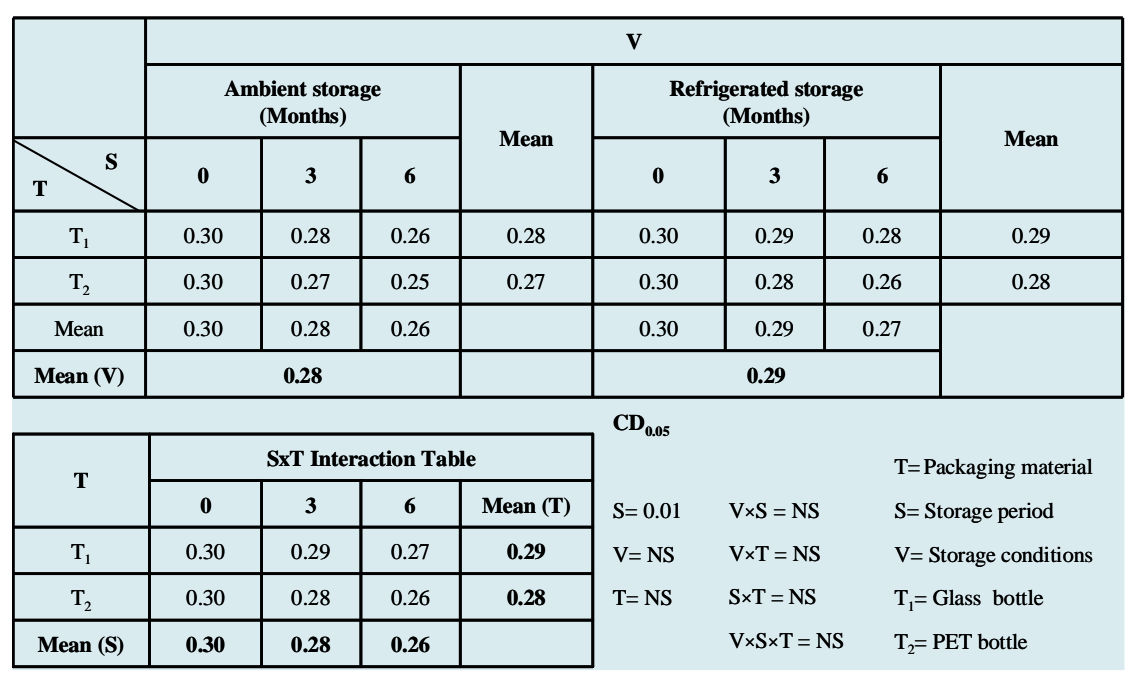


Table 8: Effect of packaging on $\mathrm{pH}$ of rhododendron drink during storage

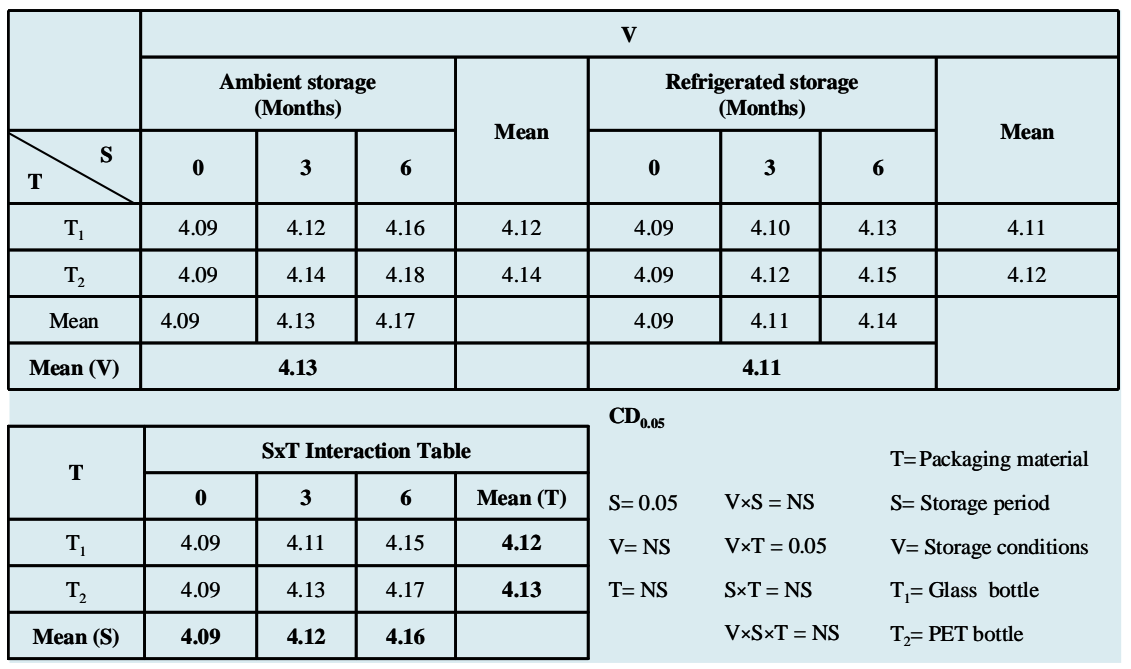

Table 9: Effect of packaging on ascorbic acid $(\mathrm{mg} / 100 \mathrm{ml})$ of rhododendron drink during storage

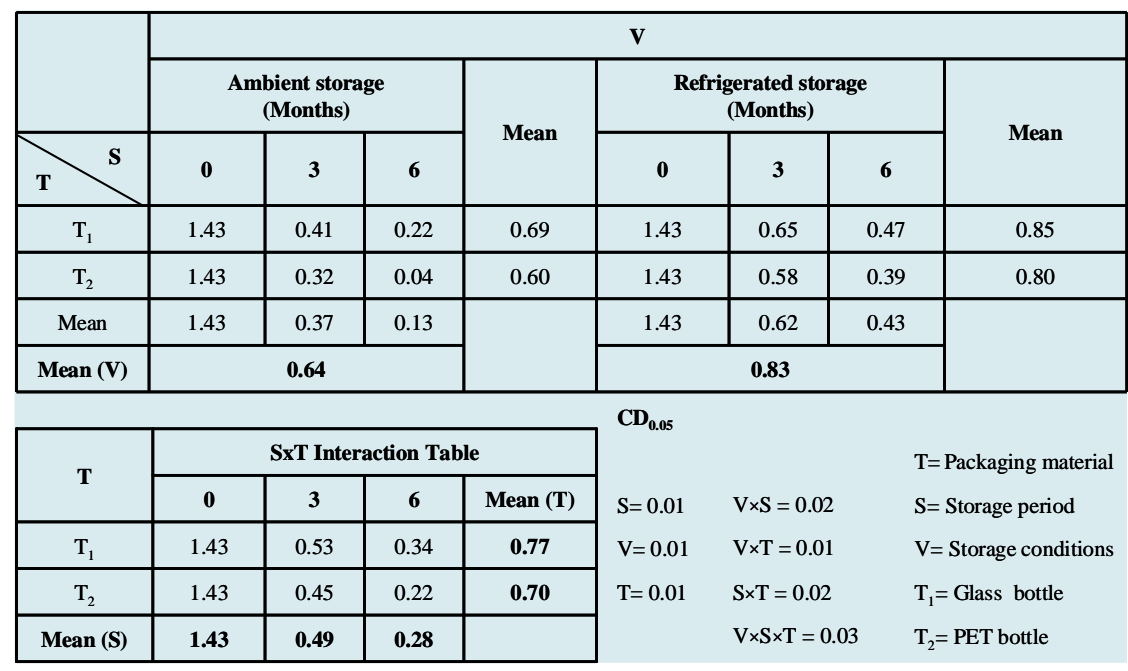

Table 10: Effect of packaging on anthocyanins $(\mathrm{mg} / 100 \mathrm{ml})$ of rhododendron drink during storage

\begin{tabular}{|c|c|c|c|c|c|c|c|c|}
\hline \multirow[b]{3}{*}{$\mathrm{T}$} & \multicolumn{8}{|c|}{$\mathbf{v}$} \\
\hline & \multicolumn{3}{|c|}{$\begin{array}{c}\text { Ambient storage } \\
\text { (Months) }\end{array}$} & \multirow{2}{*}{ Mean } & \multicolumn{3}{|c|}{$\begin{array}{l}\text { Refrigerated storage } \\
\text { (Months) }\end{array}$} & \multirow{2}{*}{ Mean } \\
\hline & $\mathbf{0}$ & 3 & 6 & & $\mathbf{0}$ & 3 & 6 & \\
\hline$T_{1}$ & 9.68 & 6.72 & 5.51 & 7.30 & 9.68 & 8.19 & 7.49 & 8.45 \\
\hline$T_{2}$ & 9.68 & 6.37 & 5.12 & 7.06 & 9.68 & 8.03 & 7.21 & 8.31 \\
\hline Mean & 9.68 & 6.55 & 5.32 & & 9.68 & 8.11 & 7.35 & \\
\hline $\operatorname{Mean}(\mathrm{V})$ & \multicolumn{3}{|c|}{7.18} & & \multicolumn{3}{|c|}{8.38} & \\
\hline & & & & & $\mathbf{C D}_{0.05}$ & & & \\
\hline \multirow{2}{*}{$\mathbf{T}$} & \multicolumn{4}{|c|}{ SxT Interaction Table } & & & \multirow{2}{*}{\multicolumn{2}{|c|}{$\begin{array}{l}\mathrm{T}=\text { Packaging materia } \\
\mathrm{S}=\text { Storage period }\end{array}$}} \\
\hline & $\mathbf{0}$ & 3 & 6 & Mean (T) & $S=0.04$ & $\mathrm{~V} \times \mathrm{S}=0.06$ & & \\
\hline$T_{1}$ & 9.68 & 7.46 & 6.50 & 7.89 & $V=0.03$ & \multicolumn{2}{|c|}{$\mathrm{V} \times \mathrm{T}=0.05$} & $\mathrm{~V}=$ Storage conditions \\
\hline $\mathrm{T}_{2}$ & 9.68 & 7.20 & 6.17 & 7.69 & $\mathrm{~T}=0.03$ & \multicolumn{2}{|c|}{$\mathrm{S} \times \mathrm{T}=0.05$} & $T_{1}=$ Glass bottle \\
\hline Mean (S) & 9.68 & 7.33 & 6.33 & & & \multicolumn{2}{|c|}{$\mathrm{V} \times \mathrm{S} \times \mathrm{T}=\mathrm{NS}$} & $\mathrm{T}_{2}=$ PET bottle \\
\hline
\end{tabular}


Table 11: Effect of packaging on total phenols ( $\mathrm{mg} \mathrm{GAE} / 100 \mathrm{ml}$ ) of rhododendron drink during storage

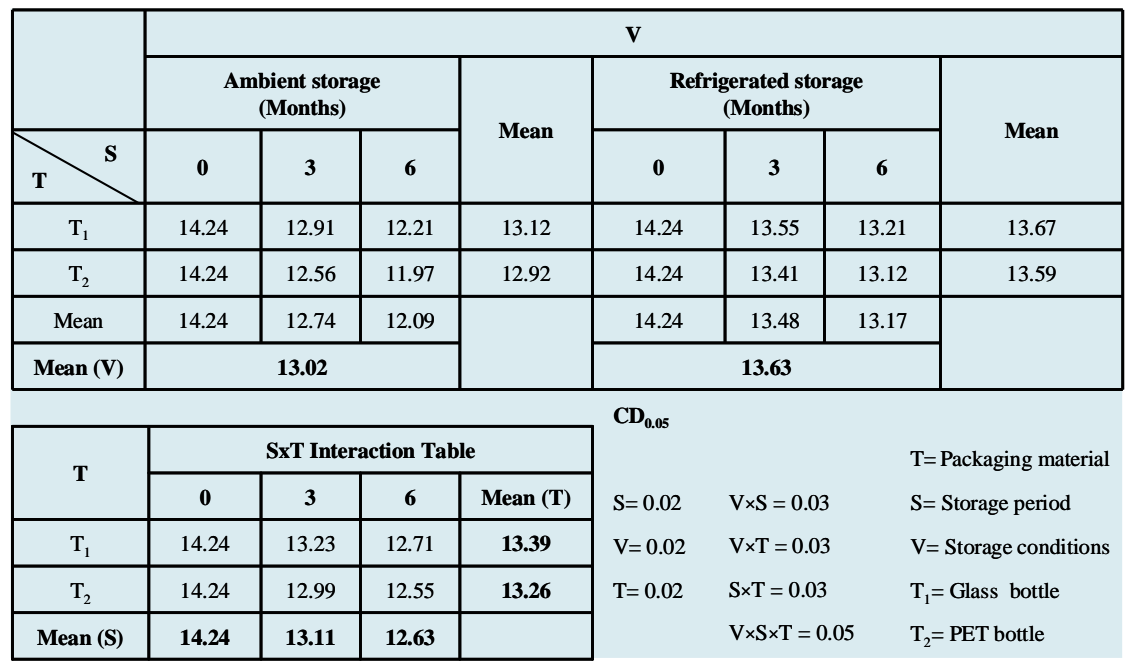

Table 12: Effect of packaging on antioxidant activity (\%) of rhododendron drink during storage

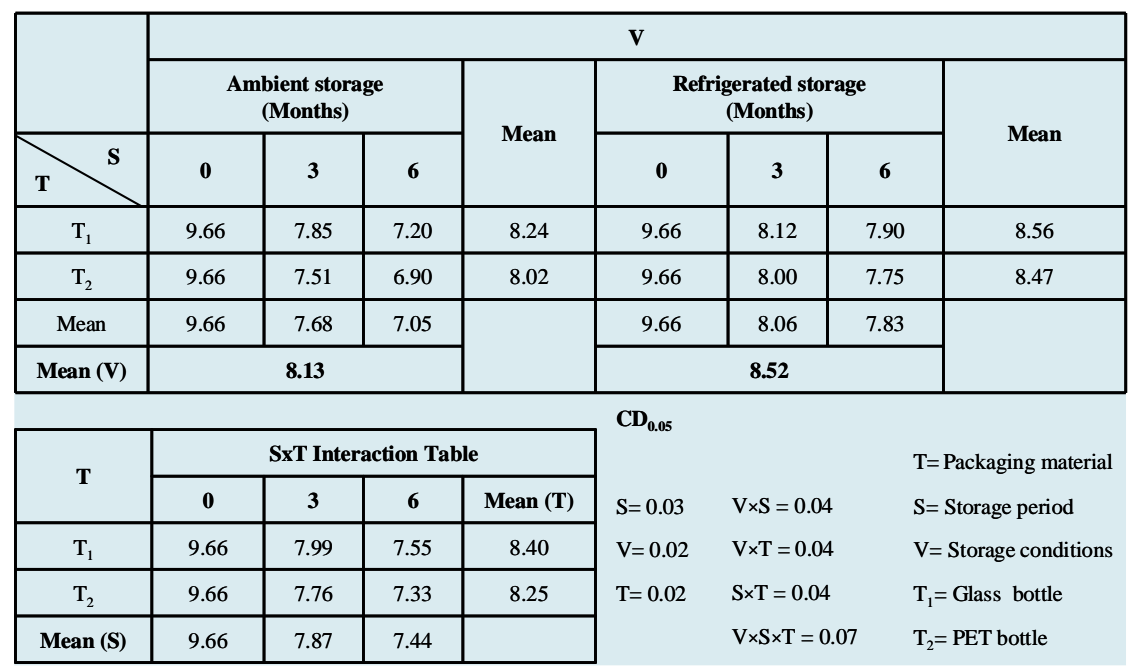

Table 13: Effect of packaging on colour scores of rhododendron drink during storage

\begin{tabular}{|c|c|c|c|c|c|c|c|c|}
\hline \multirow[b]{3}{*}{$\mathrm{T}$} & \multicolumn{8}{|c|}{$\mathbf{v}$} \\
\hline & \multicolumn{3}{|c|}{$\begin{array}{l}\text { Ambient storage } \\
\text { (Months) }\end{array}$} & \multirow{2}{*}{ Mean } & \multicolumn{3}{|c|}{$\begin{array}{l}\text { Refrigerated storage } \\
\text { (Months) }\end{array}$} & \multirow{2}{*}{ Mean } \\
\hline & 0 & 3 & 6 & & $\mathbf{0}$ & 3 & 6 & \\
\hline $\mathrm{T}_{1}$ & 8.37 & 8.00 & 7.70 & 8.02 & 8.37 & 8.20 & 8.00 & 8.19 \\
\hline $\mathrm{T}_{2}$ & 8.37 & 7.85 & 7.65 & 7.96 & 8.37 & 8.10 & 7.90 & 8.12 \\
\hline Mean & 8.37 & 7.93 & 7.68 & & 8.37 & 8.15 & 7.95 & \\
\hline Mean (V) & \multicolumn{3}{|c|}{7.99} & & \multicolumn{3}{|c|}{8.16} & \\
\hline & & & & & \multirow{6}{*}{$\begin{array}{l}\mathrm{CD}_{0.05} \\
\mathrm{~S}=0.19 \\
\mathrm{~V}=\mathrm{NS} \\
\mathrm{T}=\mathrm{NS}\end{array}$} & & & \\
\hline \multirow{2}{*}{$\mathbf{T}$} & \multicolumn{4}{|c|}{ SxT Interaction Table } & & & \multirow{5}{*}{\multicolumn{2}{|c|}{$\begin{array}{l}\mathrm{T}=\text { Packaging material } \\
\mathrm{S}=\text { Storage period } \\
\mathrm{V}=\text { Storage conditions } \\
\mathrm{T}_{1}=\text { Glass bottle } \\
\mathrm{T}_{2}=\text { PET bottle }\end{array}$}} \\
\hline & $\mathbf{0}$ & 3 & 6 & Mean $(T)$ & & $\mathrm{V} \times \mathrm{S}=\mathrm{NS}$ & & \\
\hline $\mathrm{T}_{1}$ & 8.37 & 8.10 & 7.85 & 8.11 & & $\mathrm{~V} \times \mathrm{T}=0.22$ & & \\
\hline $\mathrm{T}_{2}$ & 8.37 & 7.98 & 7.78 & 8.04 & & $\mathrm{~S} \times \mathrm{T}=\mathrm{NS}$ & & \\
\hline Mean (S) & 8.37 & 8.04 & 7.81 & & & $\mathrm{~V} \times \mathrm{S} \times \mathrm{T}=\mathrm{NS}$ & & \\
\hline
\end{tabular}


Table 14: Effect of packaging on body scores of rhododendron drink during storage

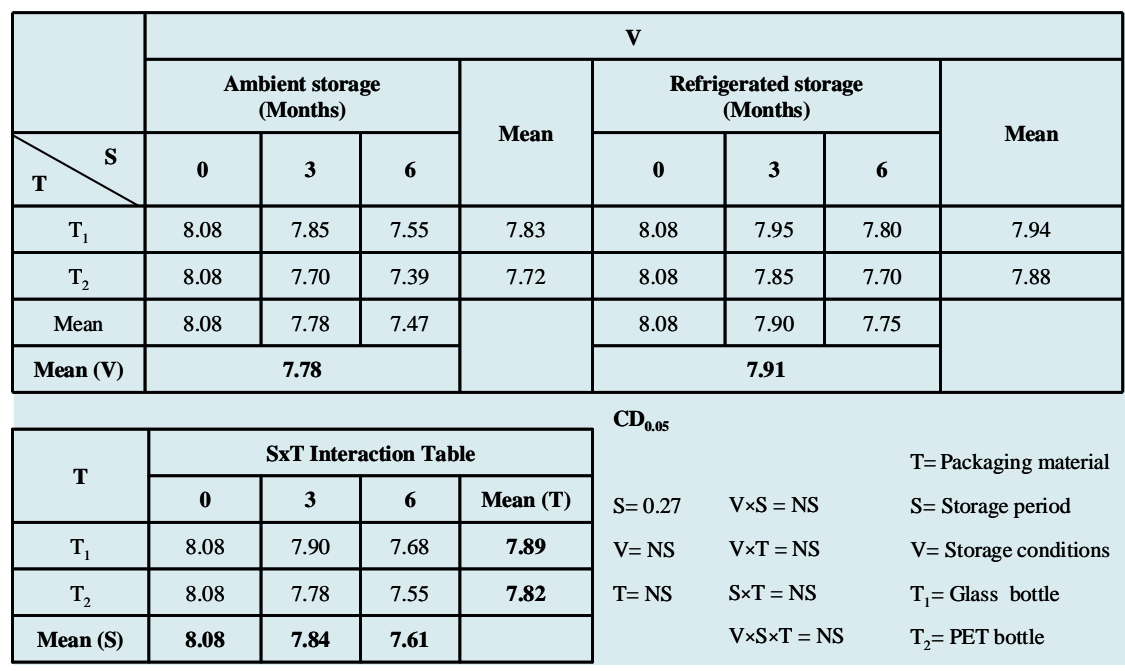

Table 15: Effect of packaging on taste scores of rhododendron drink during storage

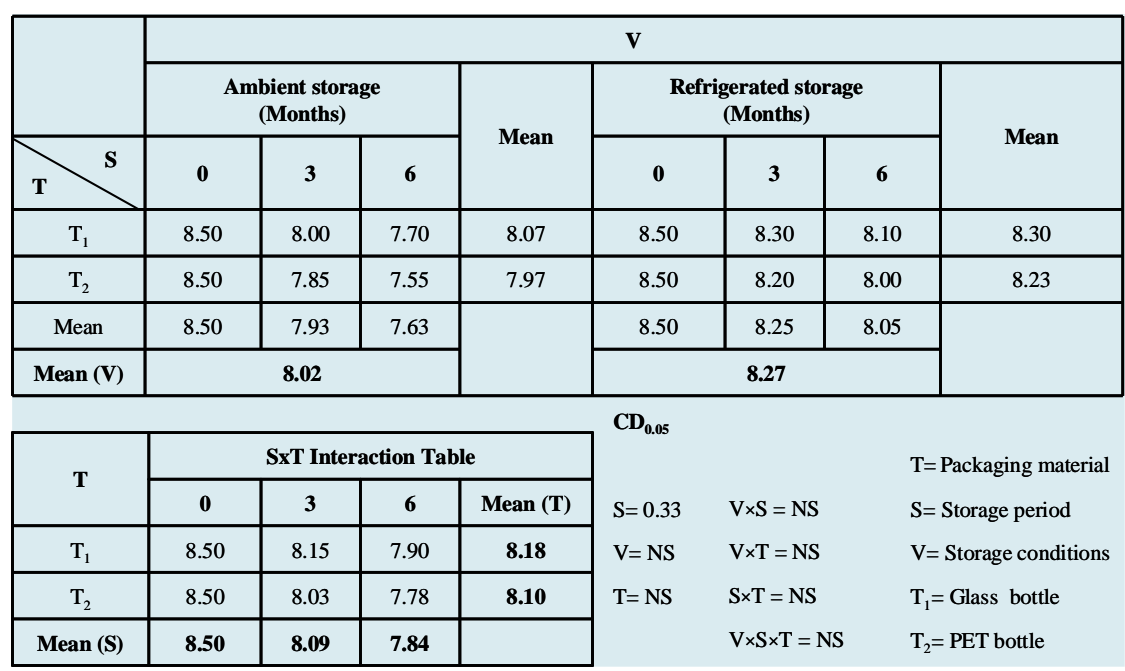

Table 16: Effect of packaging on aroma scores of rhododendron drink during storage

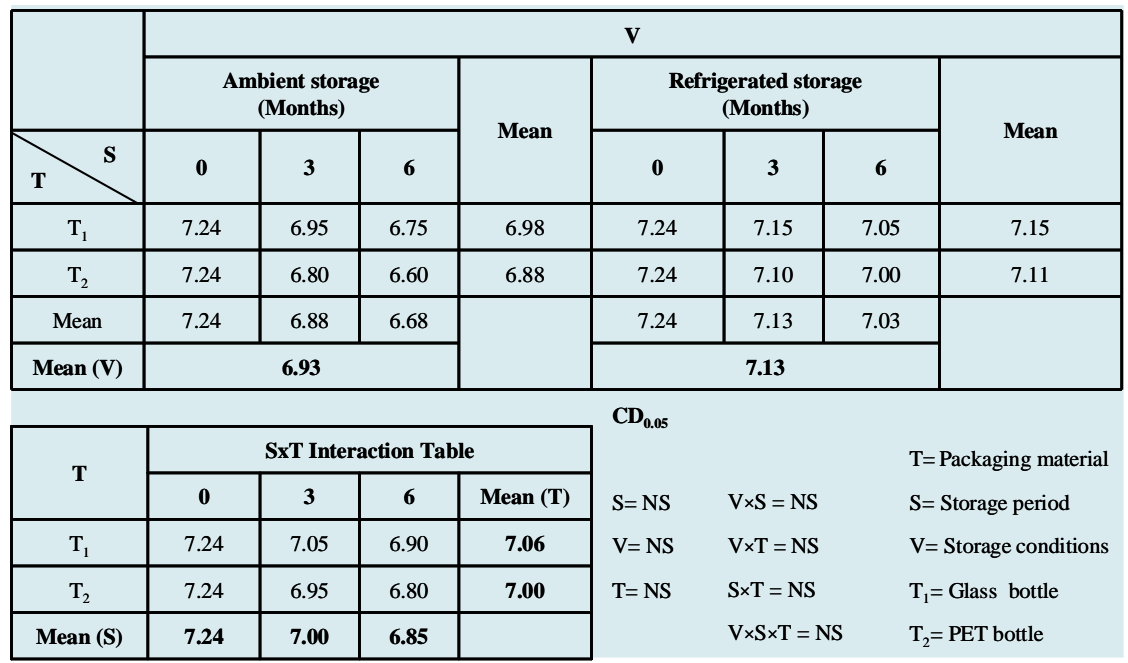


Table 17: Effect of packaging on overall acceptability scores of rhododendron drink during storage

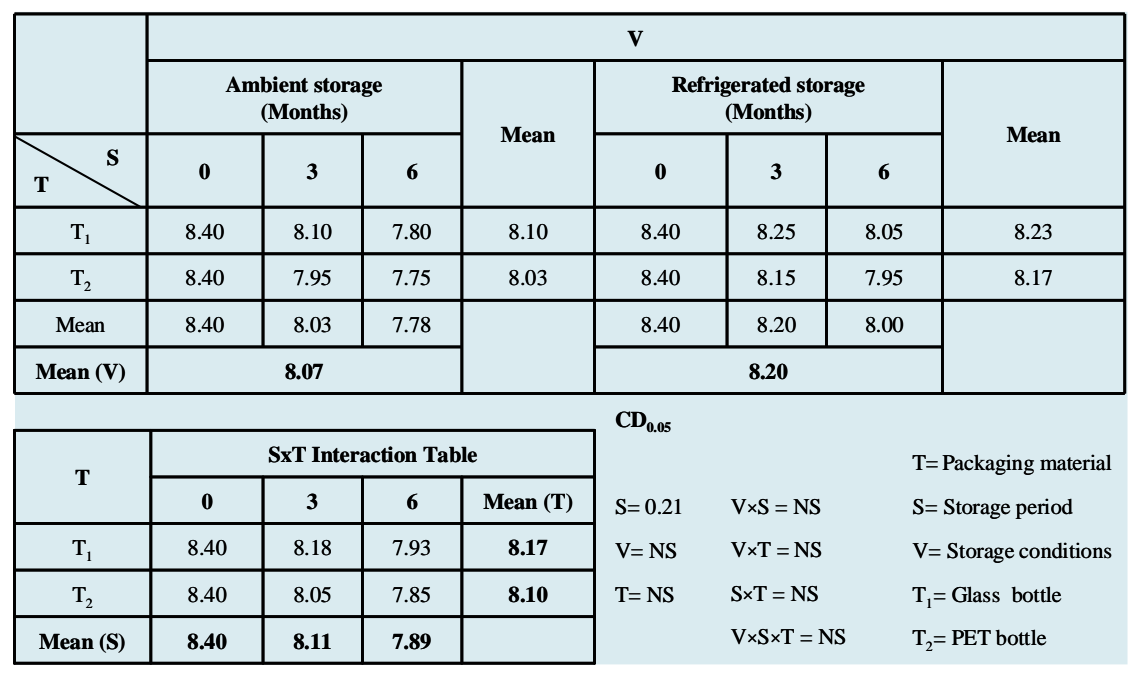

\subsubsection{TSS, reducing sugars and total sugars}

Data appended in Table 4 and Figure 1d indicates a general increasing trend in TSS of drink from 12.00 to $12.47{ }^{\circ} \mathrm{B}$. The overall effect of storage conditions as well as packaging materials on TSS of drink was statistically non-significant. Critical look of the data in Table 5 and Figure 1e shows that there was a general increasing trend of reducing sugars of drink during storage. The overall effect of storage conditions and storage period on the reducing sugars of drink reveals that it increased from 7.05 to 8.62 per cent, higher $(8.72 \%)$ were found in ambient storage conditions and lower $(7.31 \%)$ in refrigerated storage conditions. The higher $(8.10 \%)$ reducing sugars were recorded in drink packed in PET bottle as compared to glass (7.93\%) bottle while comparing the overall effect of packaging materials on reducing sugars of drink. The data in Table 6 and Figure 1f shows that the overall effect of storage period, storage conditions and packaging material on total sugars content of drink was found to be non significant.

\subsubsection{Titratable acidity and $\mathrm{pH}$}

Scrutiny of data presented in Table 7 and Figure $1 \mathrm{~g}$ indicates that there was a general decreasing trend in the titratable acidity of rhododendron drink during entire storage period of six months. The acidity of drink decreased from 0.30 to 0.26 per cent during storage irrespective of packaging materials and storage conditions. It is evident from the data given in Table 8 and Figure $1 \mathrm{~h}$ that there was a negligible increase in $\mathrm{pH}$ content of drink during the entire storage period. The overall effect of storage period shows that $\mathrm{pH}$ increased from 4.09 to 4.16 during storage irrespective of packaging materials and storage conditions. The overall effect of storage conditions as well as packaging materials on $\mathrm{pH}$ of drink found to be nonsignificant.

\subsubsection{Ascorbic acid and anthocyanins}

Table 9 and Figure 1i reveals that there was a general decrease in ascorbic acid content of drink during storage. The overall effect of storage period and storage conditions on ascorbic acid content of drink shows that ascorbic acid decreased from 1.43 to $0.28 \mathrm{mg} / 100$ $\mathrm{ml}$ and retained higher $(0.83 \mathrm{mg} / 100 \mathrm{ml})$ in refrigerated conditions and lower $0.64 \mathrm{mg} / 100 \mathrm{ml}$ in ambient storage conditions. The higher $(0.77 \mathrm{mg} / 100 \mathrm{ml})$ ascorbic acid was retained in glass bottle as compared to PET bottle $(0.70 \mathrm{mg} / 100 \mathrm{ml})$ during storage. The data in the Table 10 and Figure $1 \mathrm{j}$ indicate that there was a general decrease in anthocyanins content from 9.68 to $6.33 \mathrm{mg} / 100 \mathrm{ml}$, retained more $(8.38 \mathrm{mg} / 100 \mathrm{ml})$ in refrigerated storage conditions as compared to ambient conditions $(7.18 \mathrm{mg} / 100 \mathrm{ml})$. While studying the overall effect of packaging materials on anthocyanins content of this product, higher $(7.89 \mathrm{mg} / 100 \mathrm{ml})$ anthocyanins content was recorded in drink packed in glass bottle and lower $(7.69 \mathrm{mg} / 100 \mathrm{ml})$ in PET bottle.

\subsubsection{Total phenols and antioxidant activity}

An appraisal of data in Table 11 and Figure 1k reveals that there was a general decreasing trend in total phenols content of drink during entire storage period from 14.24 to $12.63 \mathrm{mg} \mathrm{GAE} / 100 \mathrm{ml}$. Further, while comparing the overall effect of storage conditions, it was found that more $(13.63 \mathrm{mg} \mathrm{GAE} / 100 \mathrm{ml})$ phenols were retained under refrigerated storage conditions as compared to ambient (13.02 $\mathrm{mg} \mathrm{GAE} / 100 \mathrm{ml}$ ) storage conditions. The overall effect of packaging materials indicates that more $(13.39 \mathrm{mg} \mathrm{GAE} / 100 \mathrm{ml})$ phenols were retained in glass bottle as compared to PET bottle (13.26 mg GAE/ $100 \mathrm{ml}$ ) during storage. The data in the Table 12 and Figure 11 indicate that there was a general decrease in antioxidant activity of drink from 9.66 to 7.44 per cent, retained more $(8.52 \%)$ in refrigerated storage conditions as compared to ambient $(8.13 \%)$. The higher $(8.40 \%)$ antioxidant activity was recorded in drink packed in glass bottle and lower $(8.25 \%)$ in PET bottle, while studying the overall effect of packaging materials on antioxidant activity of this product.

\subsubsection{Sensory characteristics}

Data pertaining to all sensory parameters of drink have been presented in Tables 13 to 17 and Figures 2-5. The data in Table 13 show a general decrease in colour score of rhododendron drink during storage. The overall effect of storage period indicates that colour score decreased from 8.37 to 7.81 . While, overall effect of storage conditions and packaging material on colour score of the 
product was found to be non-significant. The data given in Table 14 show that there was a general decreasing trend of body score of rhododendron drink during storage. The overall effect of storage period on body score of drink shows that it decreased from 8.08 to 7.61. Further, overall effect of storage conditions and packaging materials on body scores of the drink was found to be non-significant. Table 15 shows a general decrease in taste score of rhododendron drink during storage. The overall effect of storage period indicates that taste score decreased from 8.50 to 7.84 . While comparing overall effect of storage conditions and packaging material on taste score of the product was found to be non-significant. The data presented in Table 16 shows the overall effect of storage period, storage conditions and packaging material on aroma score of the product was found to be non-significant. The data in Table 17 highlight a general decrease in overall acceptability score of drink during entire storage period from 8.40 to 7.89 . Further, the overall effect of storage conditions and packaging materials on overall acceptability scores of the product was found to be non-significant.
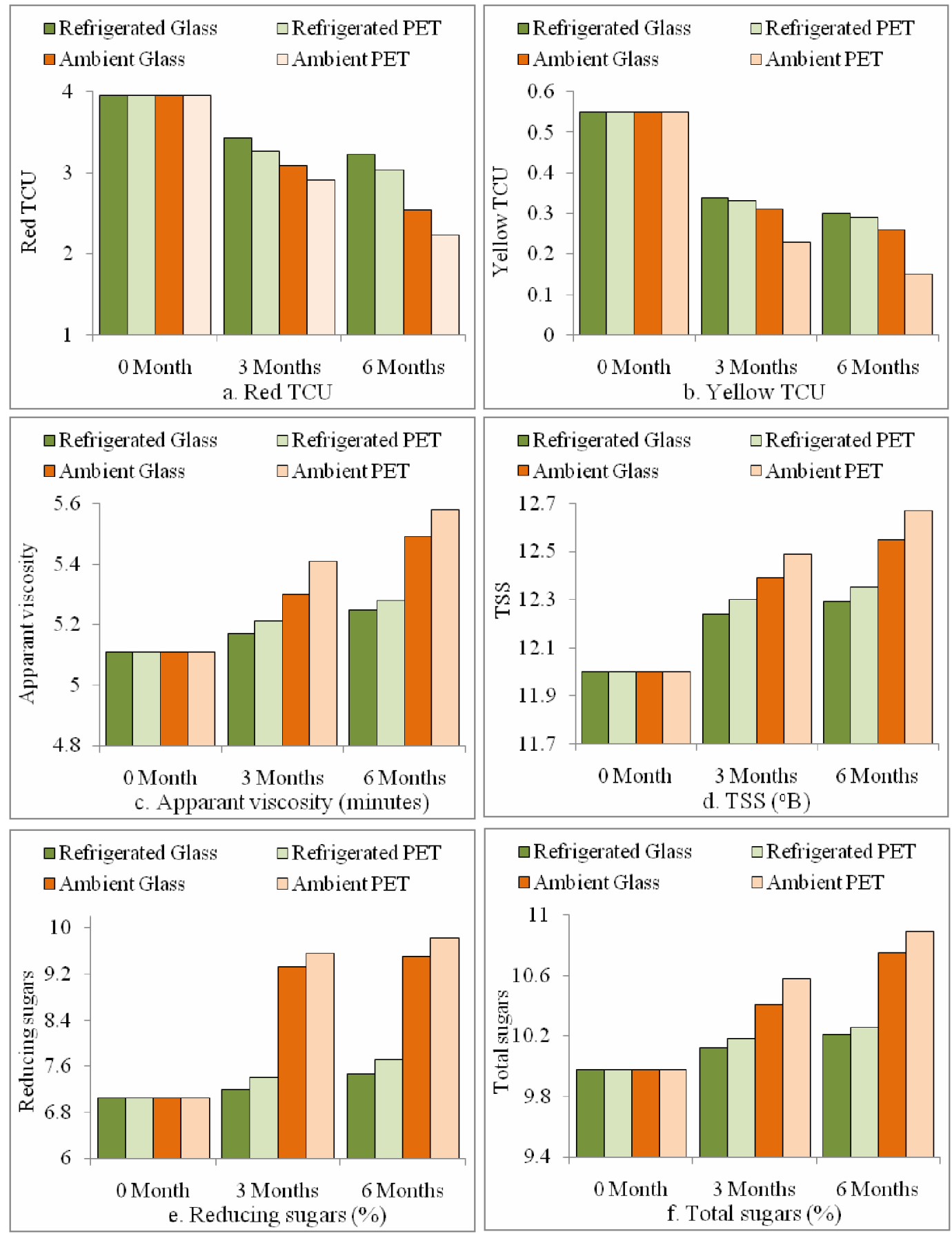

Figure 1 (a-f): Effect of storage on physicochemical characteristics of rhododendron drink. 

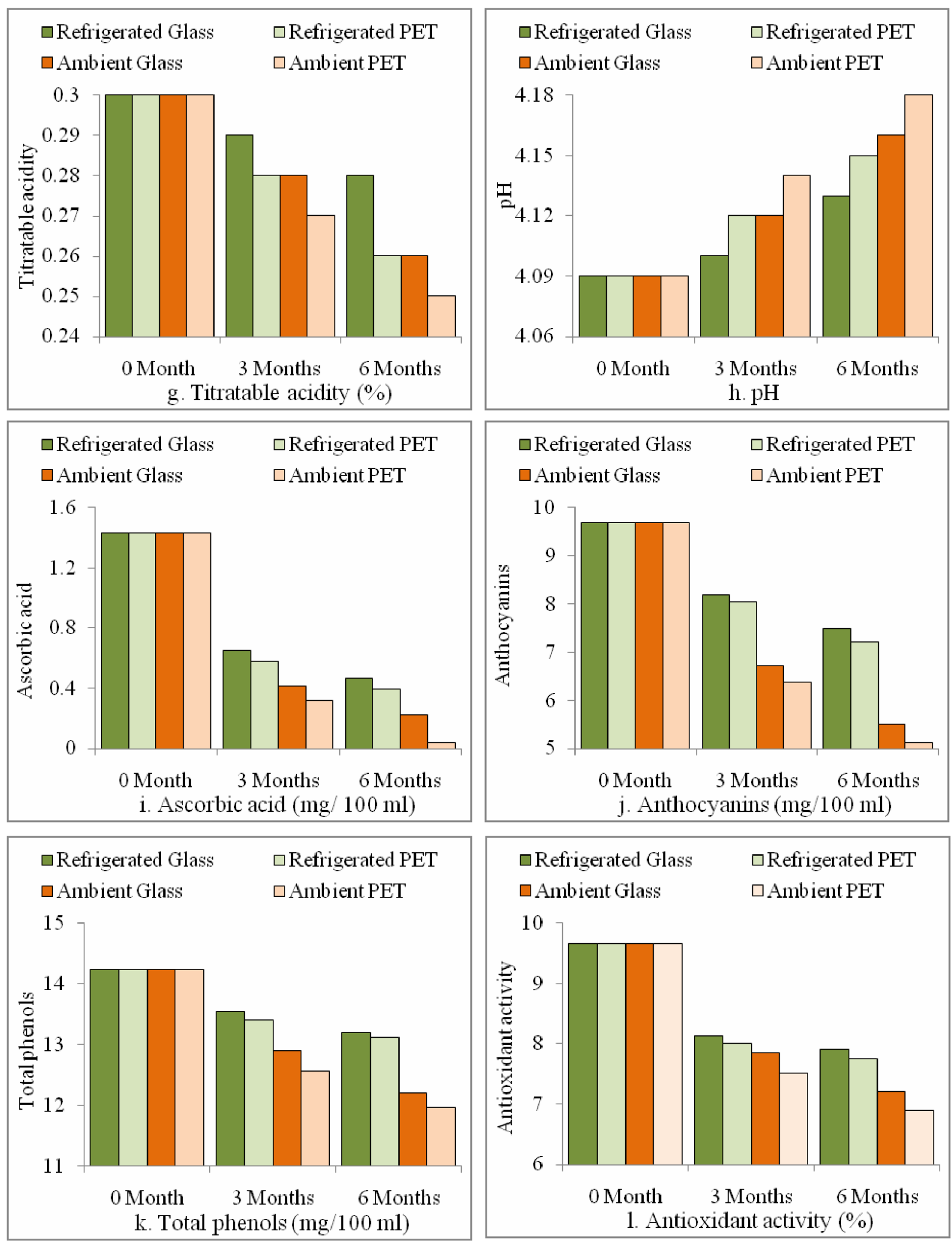

Figure 1 (g-l): Effect of storage on physicochemical characteristics of rhododendron drink. 


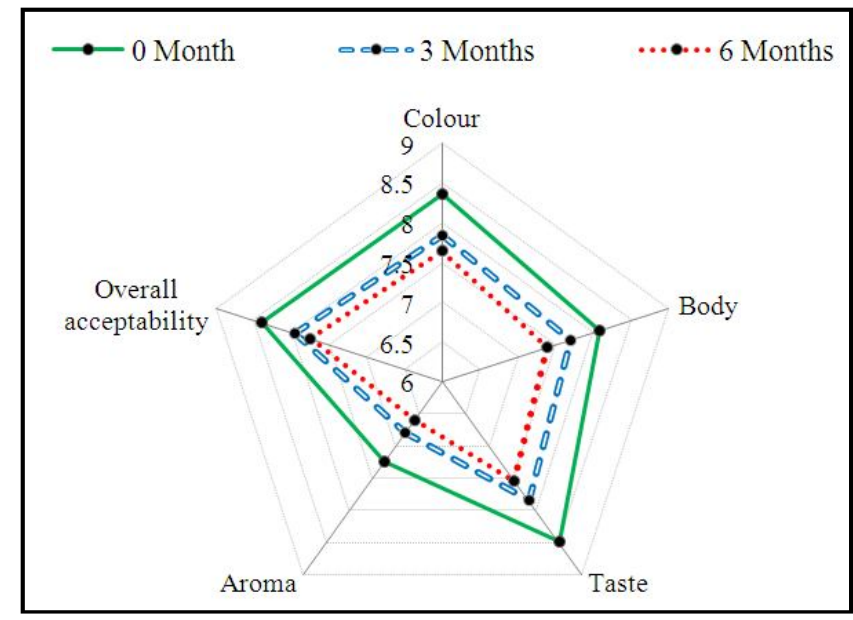

Figure 2: Effect of storage on sensory characteristics of rhododendron syrup packed in PET bottles stored under ambient conditions.

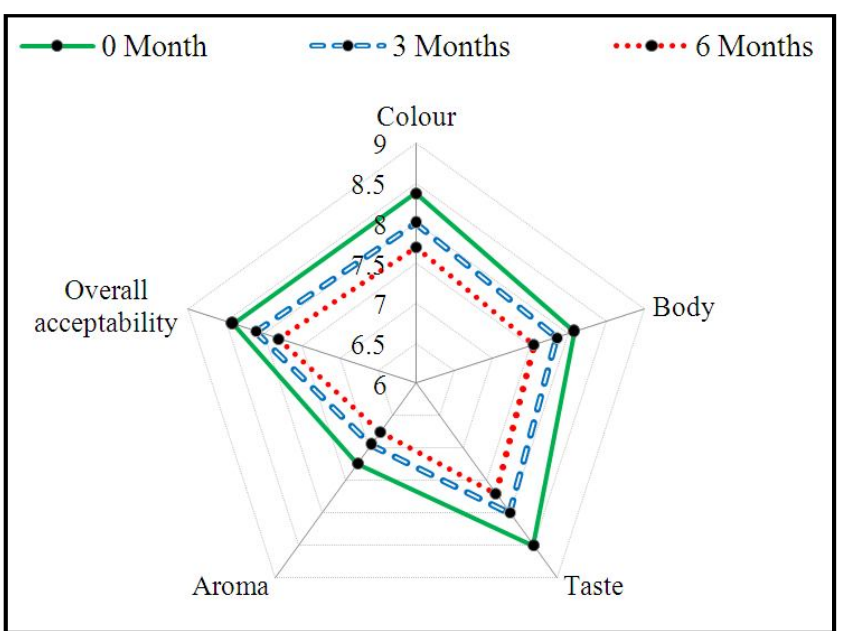

Figure 3: Effect of storage on sensory characteristics of rhododendron syrup packed in glass bottles stored under ambient conditions.

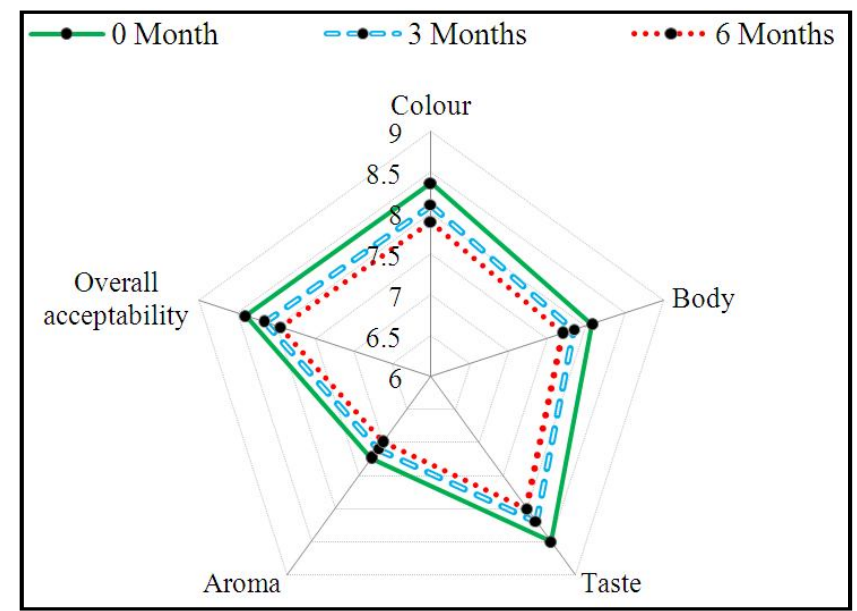

Figure 4: Effect of storage on sensory characteristics of rhododendron syrup packed in PET bottles stored under refrigerated conditions.

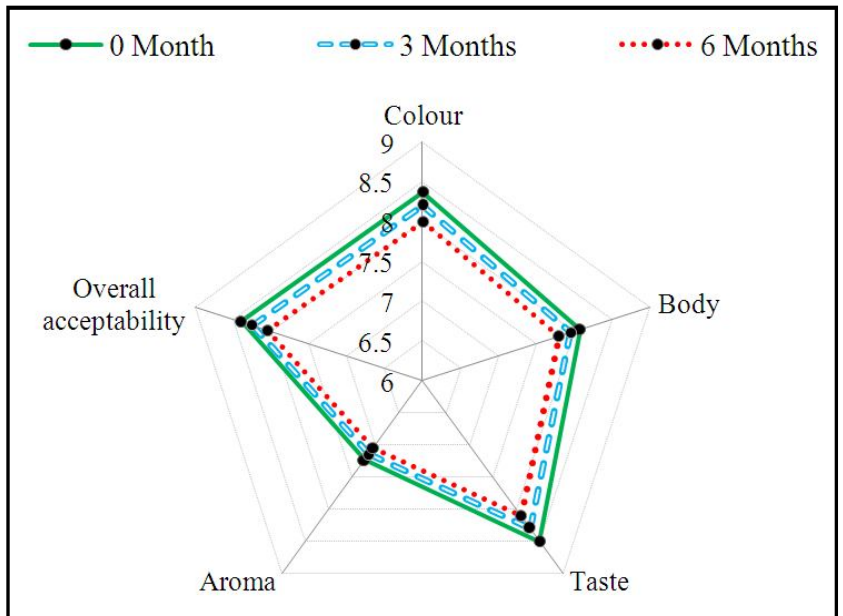

Figure 5: Effect of storage on sensory characteristics of rhododendron syrup packed in glass bottles stored under refrigerated conditions.

\section{Discussion}

\subsection{Physicochemical characteristics}

\subsubsection{Colour and apparent viscosity}

During storage, there was a significant decrease in red and yellow TCU of rhododendron drink which might be due to degradation of anthocyanins. However, anthocyanins degraded at slower rate in low temperature; hence less decrease was observed in refrigerated temperature conditions. Less decrease in colour units of drink packed in glass bottle than PET bottle was observed because of slower rate of chemical reactions in product packed in glass bottle as a result of difference in their thermal conductance properties. Apparent viscosity of rhododendron drink in terms of flow rate increased significantly during the storage period which might be due to the increase in strain, shearing rate and decrease in the flow index of the product as a result of increase in TSS and soluble sugars. As the flow index decreases it helps to develop pseudo plasticity and increased the apparent viscosity (Bal et al., 2014). Other reason could be the precipitation of drink caused due to the interaction of sugars with phenols and proteins. Similar results have been reported by Thakur et al. (2017) in box myrtle drink, Thakur et al. (2018b) in wild aonla drink and Hamid et al. (2017a) in mulberry drink.

\subsubsection{TSS, reducing sugars and total sugars}

Slight increase was experienced in TSS of rhododendron drink during storage which might be due to the hydrolysis of polysaccharides into monosaccharides and soluble disaccharides. During storage of rhododendron, drink there was a gradual increase in reducing sugars. Increase in reducing sugars during storage might be attributed due to the hydrolysis of starch into sugars. However, more increase in reducing sugars was found in drink stored under ambient temperature conditions might be due to the faster rate of reactions because of high temperature in ambient conditions. With respect to packaging material more increase in sugars recorded in drink packed in PET bottle as compared to glass bottle might be due to faster rate of chemical reactions in the product packed in PET bottle as a result of their thermal conductance properties. Similar trend of increase 
in sugars has been reported by in Chauhan et al. (2019) in wild prickly pear spiced squash, Bhatt et al. (2020a) in wild jamun squash and Thakur et al. (2020a) in rhododendron syrup.

\subsubsection{Titratable acidity and $\mathrm{pH}$}

The titratable acidity of drink showed a slight decrease during storage and this decrease might be due to co-polymerization of organic acids with sugars and amino acids. The $\mathrm{pH}$ of drink showed a slight increase during storage which might be due to the degradation of acid in the product during storage. The findings of present studies are in agreement with the results of earlier investigations reported by Satkar et al. (2015) in bitter gourd drink, Thakur and Thakur (2017) in box myrtle syrup and Thakur et al. (2020b) in spiced beverage prepared from rhododendron flowers.

\subsubsection{Ascorbic acid and anthocyanins}

The ascorbic acid content of drink decreased with the advancement of storage period however, decrease was significantly lower under refrigerated conditions as compared to ambient conditions. Decrease in ascorbic acid content during storage might be due to its degradation into dehydro-ascorbic acid or furfural. Ascorbic acid is highly sensitive to heat, therefore its degradation was more in ambient conditions. Lower decrease in ascorbic acid of drink packed in glass bottle observed during storage might be due to the slower rate of reactions in it as glass materials absorb heat slower than PET material. A significant decrease in anthocyanins content of drink was recorded during the storage and more retention of anthocyanins was observed under refrigerated storage conditions than ambient conditions. Loss of anthocyanins in drink might be due to their high susceptibility to auto oxidative degradation during storage. More retention of this parameter in the product might be due to slower rate of auto oxidation of anthocyanins in the product under refrigerated storage conditions as compared to ambient. More retention of anthocyanins of drink packed in glass bottle during storage might be due to the slower rate of reactions in glass bottle than PET as a result of difference in their thermal conductance properties. Our results are in accordance with the findings of Satkar et al. (2015) in bitter gourd drink, Hamid et al. (2017b) in mulberry syrup and Sharma et al. (2019) in apple-whey based herbal functional ready-to-serve beverage.

\subsubsection{Total phenols and antioxidant activity}

A gradual decrease in total phenols content of drink was observed during storage, which was slower under refrigerated storage conditions than ambient conditions. Significant decrease in total phenols content during storage might be due to their involvement in the formation of polymeric compounds complex of phenols with protein and their subsequent precipitations. Slower rate of loss of total phenols in refrigerated storage might be due to slower reaction rate in refrigerated conditions as compared to ambient. However, retention of more total phenols content of drink in glass bottle might also be because of slower reaction rates in glass bottle, as glass material absorb heat at slower rate as compared to PET. A gradual decrease in antioxidant activity of drink was observed during storage, which was slower under refrigerated storage conditions than ambient conditions. Significant decrease in antioxidant activity during storage might be due to the degradation of its chemical characteristics like ascorbic acid, total phenols, and anthocyanins and other reason could be the non-enzymatic browning reactions
(Thakur et al., 2021b). Slower rate of loss of antioxidant activity in refrigerated storage might be due to slower reaction rate in refrigerated conditions as compared to ambient. However, more antioxidant activity of drink in glass bottle may also be because of slower reaction rates in glass bottle, as glass material absorb heat at slower rate as compared to PET. Nearly, similar observations were recorded by Thakur et al. (2016) in box myrtle appetizer and Thakur et al. (2020c) in betalains rich drink prepared from wild prickly pear fruit.

\subsection{Sensory characteristics}

The colour scores of drink decreased significantly during storage and retained better in refrigerated storage conditions than ambient conditions. Decrease in colour score during storage might be due to browning caused by co-polymerization of organic acids of the product and this might have led the judges to award the lower scores during storage. Body scores of drink decreased with advancement of storage. The possible reason for decrease in body scores might be due to the formation of precipitates in the product as a result of interactions between phenols and protein as well as the formation of cation complexes with phenols during storage, which led the judges to award lower scores. There was a decrease in taste scores of drink with advancement of storage period which might be due to the loss of sugar-acid blend responsible for taste during storage. The overall acceptability scores of drink decreased significantly during storage which might be due to the loss in appearance, flavour compounds and uniformity of the product. Similar observations for decrease in sensory scores of the product during storage were noticed by Akhtar et al. (2013) in pomegranate drink, Chauhan et al. (2018) in beverage prepared from wild prickly pear, Bhatt et al. (2020b) in wild jamun syrup, Sharma et al. (2020) in fructooligosaccharide fortified low calorie apple-whey based RTS beverage and Thakur et al. (2020b) in spiced beverage prepared from rhododendron flowers.

\section{Conclusion}

The rhododendron drink can safely be stored for a period of six months after using appropriate packaging material. Though, the drink was found to be in good condition under both the storage conditions and in packaging material after six months of storage yet, products packed in glass packaging material and stored under refrigerated storage conditions showed slightly slower changes in terms of chemical and sensory characteristics as compared to those packed in PET packaging material and stored under ambient conditions. Moreover, the retention of chemical constituents like ascorbic acid, anthocyanins, total phenols and antioxidant activity were also retained more in the products packed in glass packaging material and stored under refrigerated storage conditions.

\section{Conflict of interest}

The authors declare that there are no conflicts of interest relevant to this article.

\section{References}

Akhtar, S.; Ali, J.; Javed, B. and Khan, F.A. (2013). Studies on the preparation and storage stability of pomegranate juice based drink. MiddleEast Journal of Scientific Research, 16:191-195.

Amerine, M.A.; Pangborn, R.M. and Roessler, E.B. (1965). Principles of sensory evaluation of food. Academic Press, London, pp:236-268. 
Bal, L.M.; Ahmad, T.; Senapati, A.K. and Pandit, P.S. (2014). Evaluation of quality attributes during storage of guava nectar cv. Lalit from different pulp and TSS ratio. Food Processing and Technology, 5:349-353.

Bhatt, K.; Thakur, N.S.; Thakur, A.; Hamid and Sharma, C. (2020a) Standardization of recipe for the preparation of wild jamun squash: effect of packaging materials and temperature conditions on nutritional quality during storage. International Research Journal of Pure and Applied Chemistry, 21(12):34-44. https://doi.org/ 10.9734/IRJPAC/2020/v21i1230232.

Bhatt, K.; Thakur, N.S.; Hamid; Thakur, A. and Sharma, C. (2020b). Optimization of juice and total soluble solids concentration for the preparation of wild jamun syrup: effect of packaging materials and temperature conditions on nutritional quality during storage. Current Journal of Applied Science and Technology, 39:116-124.

Bhattacharyya, D.M. and Sanjappa, M. (2008). Rhododendron habitats in India. Journal American Rhododendrons Society, 62:14-18.

Brand-Williams, W.; Cuvelier, M.E. and Berset, C. (1995). Use of free radical method to evaluate antioxidant activity. Lebensmittel Wissenschaft-Food Science and Technology, 28:25-30.

Chauhan, M.; Thakur, N.S. and Thakur, A. (2019). Development of spiced squash (appetizer) from wild prickly pear (Opuntia dillenii Haw.) and its quality evaluation during storage. Journal of Applied and Natural Science, 11(2):315-320. https://www.doi.org/10.31018/ jans.v11i2.2049.

Chauhan, M.; Thakur, N.S.; Sharma, R.; Thakur, A. and Hamid. (2018). Studies on development and storage quality of syrup prepared from wild prickly pear fruit. Journal of Hill Agriculture, 9:345-351.

Chauhan, N.S. (1999). Medicinal and aromatic plants of Himachal Pradesh, Indus Publishing Company, New Delhi, pp:553.

Hamid; Thakur, N.S.; Kumar, P. and Thakur, A. (2017a). Studies on preparation and preservation of Ready-to-serve (RTS) beverage from underutilized mulberry (Morus alba L.) fruits and its quality evaluation during storage. International Journal of Current Microbiology and Applied Sciences, 6(9):1067-1079.

Hamid; Thakur, N.S.; Kumar, P. and Thakur, A. (2017b). Development of syrup from mulberry (Morus alba L.) and its quality evaluation under ambient and refrigerated storage conditions. International Journal of Bio-resource and Stress Management, 8:116-121.

Kashyap, P.; Anand, S. and Thakur, A. (2017). Evaluation of antioxidant and antimicrobial activity of Rhododendron arboreum flowers extract. Int. J. Food Ferment. Tech., 7(1):123-128. https:// www.doi.org/10.5958/2277-9396.2017.00013.7.

Katoch, R.C. (2014). Phytosociety and regenration studies of Rhododendron companulatum D. M.Sc Thesis. Dr Y S Parmar University of Horticulture and Forestry, Nauni, Solan (HP), pp:70.

Kumar, V.; Suri, S.; Prasad, R.; Gat, Y.; Sangma, C.; Jakhu, H. and Sharma, M. (2019). Bioactive compounds, health benefits and utilization of Rhododendron: a comprehensive review. Agriculture and Food Security, 8:2-7.

Negi, V.S.; Maikhuri, R.K.; Rawat, L.S. and Chandra, A. (2013). Bioprospecting of Rhododendron arboreum for livelihood enhancement in central Himalaya, India. Environ. We: Int. J. Sci. Technol., 8:61-70.

Nisar, M.; Ali, S.; Qaisar, M.; Gilani, S.N.; Shah, M.R.; Khan, I. and Ali, G. (2013) Antifungal activity of bioactive constituents and bark extracts of Rhododendron arboreum. Bangladesh J. Pharmacol., 8:218-222.

Pradhan, U.C. and Lachungpa, S.T. (1990). Sikkim-Himalayan rhododendron Primulaceae Books, Darjeeling, pp:450.

Purohit, C.S. (2014). Rhododendron arboreum Sm.: An economically important tree of Sikkim. Popular Kheti, 2:193-198.
Ranganna, S. (2009). Handbook of analysis and quality control for fruit and vegetable products. Tata McGraw Hill Co. Ltd., New Delhi, pp:1112.

Satkar, K.P.; Kulthe, A.A. and Chalke, P.R. (2015). Preparation of bitter gourd ready-to-serve beverage and effect of storage temperature on its keeping quality. The Bioscan., 8:115-117.

Sharma, R. and Thakur, A. (2019). Innovations in packaging for enhancing shelf life of horticultural produce. In: "National Seminar on Doubling Income Through Sustainable and Holistic Agriculture" organised by Society for the Advancement of Human and Nature, Solan, Himachal Pradesh on June 5-7, 2019 at Dr YS Parmar University of Horticulture and Forestry, Nauni, Solan, Himachal Pradesh, India, pp:35-43.

Sharma, R.; Choudhary, R.; Thakur, N.S. and Thakur, A. (2019). Development and quality of apple-whey based herbal functional ready-to-serve beverage. Journal of Applied and Natural Science, 11(2):291-298. https://www.doi.org/10.31018/jans.v11i2.2047.

Sharma, R.; Choudhary, R.; Thakur, N.S.; Bishist, R. and Thakur A. (2020). Optimization of fructooligosaccharide fortified low calorie applewhey based RTS beverage and its quality evaluation during storage. Current Journal of Applied Science and Technology, 39(10):1728. https://doi.org/10.9734/CJAST/2020/v39i1030625.

Sharma, U.R.; Surendra, V.; Jha, S.K.; Nitesh, S.C.; Prakash, T. and Goli. D. (2009). Evaluation of anti-inflammatory activity of Rhododendron arboreum herb extract on experimental animal. Arch. Pharm. Sci. Res., 1:58-61.

Singleton, V.L. and Rossi, J.A. (1965). Colorimetry of total phenolics with phosphomolybdic phosphotungstic acid reagent. American Journal of Enology and Viticulture, 16:144-158.

Solanki, S.N.; Huria, A.K. and Chopra, C.S. (2013). Physico chemical characteristics of buransh (Rhododendron arboreum $\mathrm{Sm}$.) a nutritious and edible flower. Journal of Hill Agriculture, 4:50-52.

Srivastava, P. (2012). Rhododendron arboreum: An overview. Journal of Applied Pharmaceutical Science, 2:158-162.

Stevens, P.F.; Luteyn, E.; Oliver, G.H.; Bell, T.L.; Crowden, R.K.; George, A.S.; Jordon, G.J.; Ladd, P.; Lewson, K.; McLeon, C.B.; Menadue, Y.; Plate, J.S.; Stace, H.M. and Weiller, C.M. (2004). Flowering plants. dicotyledons, celastrales, oxidales, rosales, ericales, ericaseae, In: Kubitzki, K (Ed.) Families and Genera of Vascular Plants, Berlin, Heidelberg, pp:145-195.

Thakur, A. and Thakur, N.S. (2017). Development of syrup from box myrtle (Myrica nagi) and its quality evaluation during storage. International Journal of Agriculture Sciences, 9:3862-3865.

Thakur, A.; Thakur, N.S. and Kumar, P. (2017). Preparation of Myrica nagi (Box myrtle) drink and effect of storage temperature on its quality. Journal of Applied and Natural Science, 9(4):2137-2142. https:// www.doi.org/10.31018/jans.v9i4.1500

Thakur, N.S.; Aarti; Thakur, A.; Hamid and Gautam, S. (2021a). Standardization of recipe for the preparation of drink from rhododendron (Rhododendron arboreum Sm.) flower extract (accepted). Journal of Phytonanotechnology and Pharmaceutical Sciences, 1(2).

Thakur, A.; Thakur, N.S.; Hamid and Gautam, S. (2021b). Effect of packaging on phenols, flavonoids and antioxidant characteristics of mechanical cabinet dried wild pomegranate (Punica granatum L.) arils. Journal of Applied and Natural Science, 13(1):101-109. https://doi.org/10.31018/jans.v13i1.2456

Thakur, N.S.; Aarti; Gautam, S.; Chandel, A.; Rana, N.; Thakur A. and Hamid (2020a). Comparative assessment of Rhododendron (Rhododendron arboreum $\mathrm{Sm}$.) flowers extract beverages through biochemical analysis and its quality evaluation during storage. Ann. Phytomed., 9(2):223-231. http://dx.doi.org/10.21276/ap.2020.9.2.20. 
Thakur, N.S.; Aarti; Hamid; Thakur, A. and Gautam, S. (2020b). Utilization of edible rhododendron (Rhododendron arboreum $\mathrm{Sm}$.) flowers for development of spiced beverage (appetizer) and its shelf life evaluation during storage. International Research Journal of Pure and Applied Chemistry, 21:52-62.

Thakur, N.S.; Chauhan, M. and Thakur, A. (2020c). Studies on development and storage quality evaluation of betalains rich drink prepared from wild prickly pear (Opuntia dillenii haw.) fruits. The Bioscan, 15(1):9-13.

Thakur, N.S.; Thakur, A. and Joshi, V.K. (2016). Development of appetizer from box myrtle (Myrica nagi) and its quality evaluation during storage. International Journal of Food and Fermentation
Technology, 6(1):151-161. https://doi.org/10.5958/2277-9396. 2016.00038 .6 .

Thakur, N.S.; Thakur, N.; Thakur, A.; Kumar, P. and Hamid. (2018a). Physicochemical characteristics and standardization of juice extraction method from wild aonla (Phyllanthus emblica L.) fruits of Himachal Pradesh, India. International Journal of Current Microbiology and Applied Sciences, 7(2):731-737. https:// www.doi.org/10.20546/ijcmas.2018.702.092

Thakur, N.S.; Thakur, N.; Hamid; Kumar, P. and ThakurA. (2018b). Formulation and optimization of vitamin $\mathrm{C}$ rich ready-to-serve juice based beverage from wild aonla fruits and its quality evaluation during storage. Journal of Pharmacognosy and Phytochemistry, 7(1):1796-1802. 